\title{
Processing of Oxidised and Sulphide Copper Ore Mixtures: Preliminary study
}

\author{
Jessica Koketso Seomane and Michel Kalenga wa Kalenga \\ \{jseomane@gmail.com, michelk@uj.ac.za\} \\ Department of Metallurgy/ Faculty of Engineering And The Built Envirnment \\ University of Johannesburg \\ P.O.BOX 17011, Johannesburg- Doornfontein 2028
}

\begin{abstract}
The Many investigations on leaching of different copper sulphide ores from different countries have been conducted and optima working conditions recommended. This work is a preliminary study of leaching of a mixture of sulphides and oxides copper ores from the Democratic Republic of Congo. With the mine deepening a mixture of oxides and sulphides copper is mined. The leaching of the mixture becoming more difficult, thus the need to find new avenues of leaching. Three categories of leaching tests were conducted. In category A, oxide and sulphide ores were separately leached with sulphuric acid where particle size influence was investigated and the best size identified as well as the optimum $\mathrm{pH}$ value. Category $\mathrm{B}$, the sulphide ore was leached with sulphuric acid in conjunction with hydrogen peroxide. An improvement in copper and cobalt dissolution was noticeable. In category $\mathrm{C}$, a mixture of oxide and sulphide ores was dissolved with sulphuric acid with hydrogen peroxide. The best mixture was found and optimum $\mathrm{pH}$ value identified with $\mathrm{pH}$ varied from 1.5 to 2.5 .
\end{abstract}

Keywords: Oxide and sulphide copper ore, processing, mixtures.

\section{Introduction}

This The leaching of a copper oxide and sulphide copper ores have been largely reported. Many investigations on the leachability on different copper sulphide ores from different countries have been conducted and optima working conditions recommended. The present work present is a preliminary study on a mixture of sulphides and oxides copper ores from Kamoto mine in the Katanga province in the Democratic Republic of Congo which is located central Africa in the copper belt region. Many investigation son different sulphides copper ores have been conducted using different oxidizing agents. Investigations on leaching of copper (I) sulphide using sulfuric acid with addition of sodium nitrate have been conducted [1]. It was found that the quantity of copper dissolved was increasing with growth of the values of all the parameters namely temperature, concentration of $\mathrm{NaNO}_{3}$ and $\mathrm{H}_{2} \mathrm{SO}_{4}$. Also, the influence of ferric ion on the leaching of chalcopyrite was investigated [2]. It was found that ferric iron plays two important roles in the leaching of chalcopyrite namely as a mineral oxidizing agent and as the agent responsible for chalcopyrite passivation. Further, investigations on the effect of redox potential on the leaching of chalcopyrite was conducted. It was found that although ferric iron is responsible for the oxidation of chalcopyrite, whilst ferrous ion also plays an important role because it was found that it controls precipitation and nucleation of jarosites, which ultimately causes passivation of the sulphide. Same researchers also found that Chalcopyrite dissolves

ACRID 2017, June 20-21, Victoria Falls, Zimbabwe

Copyright (C) 2017

DOI 10.4108/eai.20-6-2017.2270866 
through the formation of an intermediary product covellite $(\mathrm{CuS})$ that ferric ion oxidises later, releasing $\mathrm{Cu}^{2+}$ ions [3]. Furthermore, the same authors investigated the influence of adding silver as catalyst on the redox potential and found that the surface of chalcopyrite was transformed into copper-rich sulphides such as covellite and geerite [4]. Moreover, many other works have investigated the role of redox potential in the presence of some bacteria have concluded that some microorganisms may lead to solution being overoxidised. Hydrogen peroxide is one of the strong oxidizing agents and it promotes the oxidation of the ore body and leaching potential of sulphuric acid or the leaching medium used. Among the advantages of hydrogen peroxide besides its high oxidizing potential, it is easier to handle than gas oxidants. Investigations on the kinetics and mechanisms of dissolution of the major base metal sulphide minerals, pyrite, chalcopyrite, galena and sphalerite in acidic (chloride) have found that there is a development of a sulphur-rich surface during galvanically-promoted dissolution [5]. Other authors suggested that amongst the mineral sulfides, the most well studied is chalcopyrite and that for this mineral several different passivating species have been suggested more specially elemental sulfur, polysulfides, metal-deficient sulfides, jarosite and jarosite-like compounds [6].Additional investigations have provided an overview on the mineralogy and geochemistry of sulphide minerals [7] and also provided mechanisms and rate of oxidation of sulphides due to acid mine drainage [8].

The dissolution of copper sulphide minerals in the presence of hydrogen peroxide is thermodynamically feasible according to the following reactions:

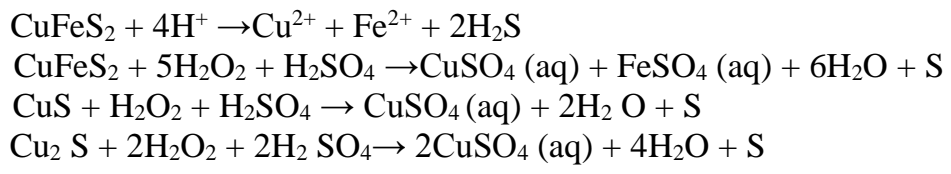

The present investigation is a preliminary work on a possible leaching of a mixed sulphideoxide copper ores from Kamoto in the Democratic Republic of Congo using hydrogen peroxide as oxidising agent.

\section{Methodology}

\subsection{Material and experimental}

XRD, XRF and SEM were used to characterise the samples. To conduct the experiments, beakers of 1 litre capacity were used and were covered to avoid high evaporation and decrease of volume of the solutions. To increase the temperature, hot plats equipped with magnetic agitator were used. $10 \mathrm{~g}$ of ore were used in all the experiments. The agitation rate was $100 \mathrm{rpm}$. This was decided as velocity to avoid the formation of a vortex which would possibly dissolve oxygen from air and disturb the process. Time varied from 30min to $90 \mathrm{~min}$ with $30 \mathrm{~min}$ increase while the temperature was increased from 25 to 40 and $50^{\circ} \mathrm{C}$. For category A, $100 \mathrm{ml}$ of sulfuric acid were used whereas for category $\mathrm{B}$ sulfuric acid was coupled with hydrogen peroxide in couples of $(90,10) ;(80,20) ;(60,40)$ and $(50,50) \mathrm{ml}$. In category $\mathrm{C}$, the proportions of oxide and sulphide were coupled in $(90,10) ;(80,20)$ and $(70,30)$ while the volumes of sulfuric acid and hydrogen peroxide were 90 and $10 \mathrm{ml}$ respectively. 


\subsection{Characterisation}

The experiment uses two types of Copper ore samples, copper sulphide and copper oxide ore. The two samples are from Kamoto Oliveira Virgule (KOV) mine located in Katanga province in the DRC. A representative sample was dried, screened using various screen sizes for 30 minutes, shown in tables 1 and 2 below.

From the CUM mass percentage passing it could be observed that the sulphide ores had higher CUM mass \% passing than the oxide ore for the sizes $-150+160 \mu \mathrm{m}$ and $-160+75 \mu \mathrm{m}$. But the $-75 \mu \mathrm{m}$ the oxide ore had higher CUM mass \% passing.

Table 1. Cu-Co Oxide ore screen analyses.

\begin{tabular}{llll}
\hline Aperture size $(\mu \mathrm{m})$ & Mass $(\mathrm{g})$ & Mass $\%$ & CUM mass \% passing \\
\hline+150 & 0.1 & 0.01 & \\
$-150+106$ & 164.5 & 27.8 & 99.99 \\
$-106+75$ & 123.5 & 20.9 & 72.19 \\
-75 & 302.5 & 51.2 & 51.2 \\
Total & 591 & 100 & \\
\hline
\end{tabular}

Table 2. $\mathrm{Cu}-\mathrm{Co}$ Sulphide ore screen analyses

\begin{tabular}{lccl}
\hline Aperture size $(\mu \mathrm{m})$ & Mass $(\mathrm{g})$ & Mass $\%$ & CUM mass \% passing \\
\hline+150 & 160.6 & 27.2 & \\
$-150+106$ & 122.3 & 20.7 & 72.8 \\
$-106+75$ & 123.4 & 20.9 & 52.1 \\
-75 & 183.9 & 31.2 & 31.2 \\
Total & 590 & 100 & \\
\hline
\end{tabular}

Table 3. XRF analyses of different particle sizes of $\mathrm{Cu}-\mathrm{Co}$ sulphide and oxide ores

\begin{tabular}{cllllllll}
\hline $\begin{array}{l}\text { Aperture } \\
\text { size }(\mu \mathrm{m})\end{array}$ & Mass $(\mathrm{g})$ & Mass \% & $\begin{array}{l}\text { CUM mass } \\
\% \text { passing }\end{array}$ \\
\hline Particle $(\mu \mathrm{m})$ & $\mathrm{Mg} \%$ & $\mathrm{Si} \%$ & $\mathrm{~S} \%$ & $\mathrm{Ca} \%$ & $\mathrm{Fe} \%$ & $\mathrm{Co} \%$ & $\mathrm{Cu} \%$ & $\mathrm{Al} \%$ \\
\hline$-75 \mathrm{~S}$ & 1.44 & 0.99 & 12.27 & 3.9 & 15.2 & 0.1 & 28.85 & \\
$\mathrm{O}$ & 1.32 & 36.63 & 12.01 & 4.09 & 1.8 & 0.46 & 7.53 & 1.32 \\
& 2.03 & 3.38 & 10.45 & 3.89 & 14.61 & 0.1 & 27.81 & \\
$+75 \mathrm{~S}$ & 2.96 & 36.27 & 12.01 & 4.09 & 1.85 & 0.47 & 7.64 & 1.28 \\
$\mathrm{O}$ & 1.47 & 1.04 & 12.01 & 4.09 & 15.23 & 0.11 & 28.95 & \\
& & & & & & & & \\
\hline
\end{tabular}

Table 4. XRF chemical Analyses of Representative Ore of Cu-Co sulphide and Oxide sample. 


\begin{tabular}{|c|c|c|c|c|c|c|c|c|c|c|c|}
\hline Component & $\mathrm{Mg}$ & $\mathrm{Al}$ & $\mathrm{Si}$ & $\bar{P}$ & $\bar{S}$ & $\mathrm{Ca}$ & $\mathrm{Fe}$ & $\mathrm{Co}$ & $\mathrm{Ni}$ & $\overline{\mathrm{Cu}}$ & $\mathrm{Zn}$ \\
\hline Weight $\mathrm{S}$ & 1,74 & 0,19 & 0,75 & 0,39 & 13,75 & 4,28 & 14,77 & 0,1 & 0,13 & 26,18 & 0.00 \\
\hline $\mathrm{O}$ & 3,46 & 1,41 & 36,53 & 0,25 & 0,03 & 0,32 & 1,71 & 0,44 & 0.01 & 6,81 & 0.03 \\
\hline
\end{tabular}

$* S=$ sulphide $\quad * O=$ oxide

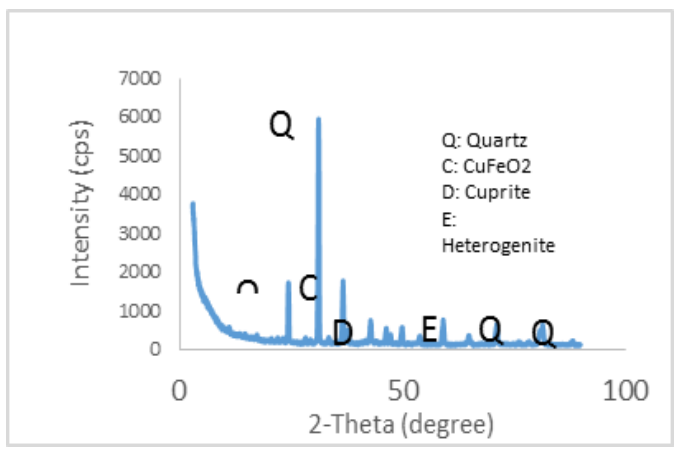

Figure 1. XRD pattern of $\mathrm{Cu}$-Co oxide

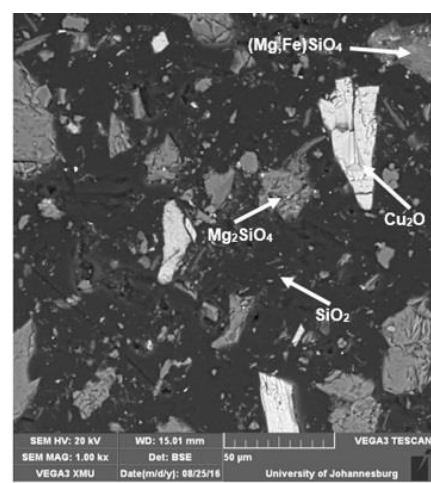

a)Oxide ore
Figure 3: SEM micrograph of polished section of copper

Table 5: Percentage of minerals: copper oxide sample.

\begin{tabular}{r|llllllllll} 
Element & $\mathrm{F}$ & $\mathrm{Mg}$ & $\mathrm{Al}$ & $\mathrm{Si}$ & $\mathrm{P}$ & $\mathrm{Cl}$ & $\mathrm{Fe}$ & $\mathrm{Cu}$ & $\mathrm{O}$ & Mineral \\
\hline Weight & 0,2 & 0,75 & 0,5 & 0,97 & 1,6 & 0,0 & 0,24 & 72,8 & 22,6 & Cuprite \\
$\%$ & 6 & & 9 & & 6 & 1 & & 3 & 8 & \\
& 1,1 & 8,61 & 0,0 & 39,3 & 0,0 & 0,0 & 0,01 & 0,27 & 50,5 & Fosterit \\
& 5 & & 2 & 7 & 1 & 2 & & & 8 & $\mathrm{e}$ \\
& 0,1 & 1,84 & 0,8 & 42,0 & 0,3 & 3,2 & 0,2 & 0,85 & 50,5 & Quartz \\
& 8 & & 3 & 2 & 3 & 1 & & & 3 &
\end{tabular}

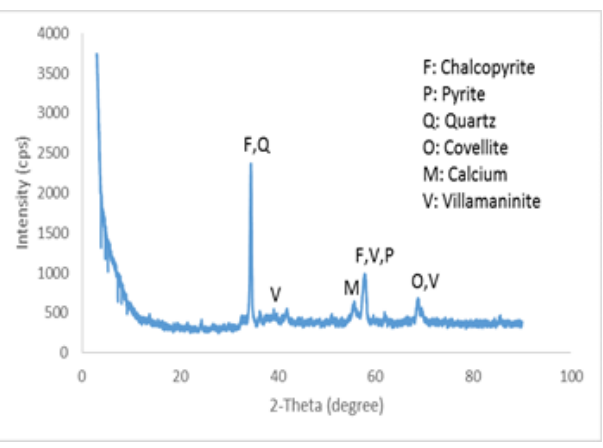

Figure 2. XRD pattern of $\mathrm{Cu}-\mathrm{Co}$ sulphide

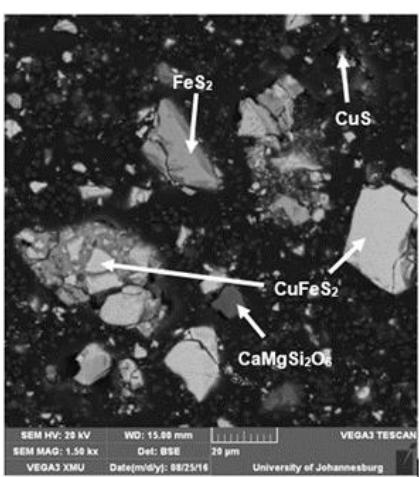

b) sulphide ore 


$$
\begin{array}{|llllllllll}
1,6 & 16,0 & 6,7 & 14,0 & 0,4 & 2,7 & 18,4 & 3,72 & 39,3 & \text { Olivine } \\
& 7 & 2 & 3 & 6 & 8 & 7 & & 6 &
\end{array}
$$

Table 6: Percentage of minerals: copper sulphide sample

\begin{tabular}{r|lllllllllll} 
Element & $M g$ & $S i$ & $S$ & $C l$ & $C a$ & $T i$ & $M n$ & $F e$ & $C u$ & $O$ & Mineral \\
\hline Weight & 0,02 & 0 & 18,3 & 0,01 & 0,02 & 0,04 & 0,01 & 7,69 & 35,6 & 38,5 & Cuprite \\
$\%$ & 10,6 & 26,5 & 0,08 & 0,01 & 16,1 & 0 & 0 & 1,8 & 0,67 & 44,3 & Fosterit \\
& 0,8 & 0,01 & 10,1 & 0,02 & 0,01 & 1,6 & 0,3 & 63,5 & 0,75 & 23 & Quartz \\
& 2,21 & 1,04 & 15,6 & 3,02 & 0,77 & 0,01 & 0,1 & 11,4 & 28,9 & 36,9 & Olivine
\end{tabular}

\section{Results and discussion}

\subsection{Leaching with sulphuric acid only on $\mathrm{Cu}-\mathrm{Co}$ oxide and sulphide ore (Part A)} 3.1.1 Effect of particle size

The effect of particle size on the dissolution of copper and cobalt was studied from $\mathrm{Cu}$-Co oxide ore (figure 1A) and sulphide ore (figure 1B). The experiment was done using different particle sizes of $100 \%$ passing $75 \mu \mathrm{m}(<75),+106-75(>75)$ and $+150-106 \mu \mathrm{m}(>106)$.
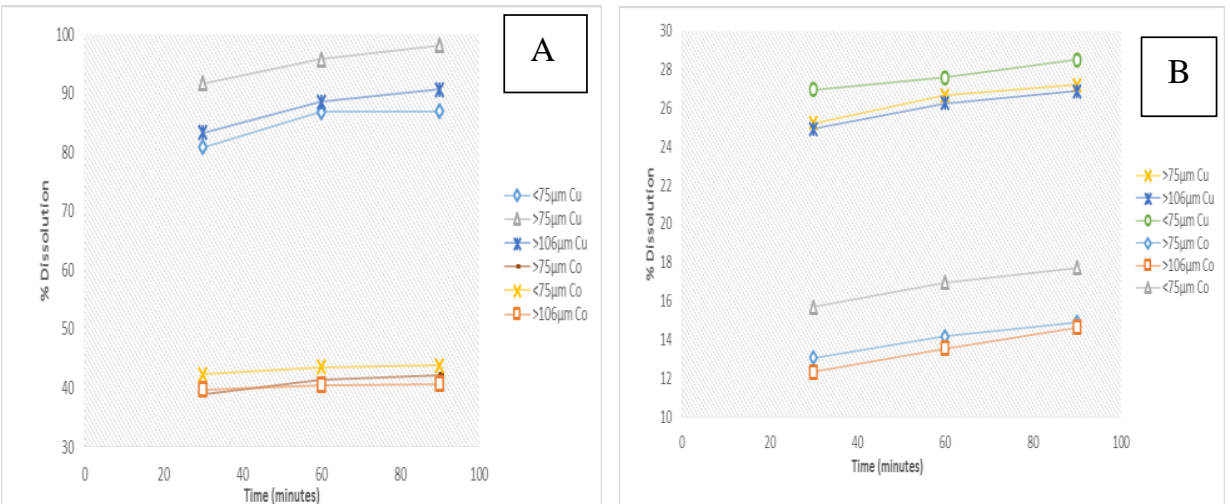

Figure 4. Effect of different particle sizes on the \%dissolution of copper and cobalt in oxide (A) and sulphide (B) ore.

Results from the oxide ore referring to figure 4A show that the $\%$ dissolution of copper and cobalt increase with a decrease in particle size. This is due to the fact that there is an increase in surface area which results in exposure of the ore particles to the leaching reaction therefore increasing contact between the leaching agent and the targeted metal. The results on the oxide ore (figure 4A) show a high percentage dissolution of copper at a particle size of $>75 \mu \mathrm{m}$ with $98.2 \%$ dissolution of copper. For cobalt the results (still on figure 4A) high percentage dissolution is obtained at a particle size of $<75 \mu \mathrm{m}$. It evident from the results shown in figure 4A that the smaller the size particles the higher the percentage dissolution of copper and cobalt. The percentage dissolution of copper and cobalt from the sulphide ores in comparison with their behaviour from the oxide was as well investigated. Results demonstrated (figure 4B) that the recovery of $\mathrm{Cu}$ and $\mathrm{Co}$ from the sulphide ores was far lower as compared to that from the oxide 
leached at the same conditions. This is due to the fact that, despite the size reduction of particle sizes aiming to expose more particles to the leaching agent, the elementary sulphur present in the sulphide mineral render this latter refractory regarding to the $\mathrm{H}_{2} \mathrm{SO}_{4}$.

\subsubsection{Effect of pH}

In this experiment the effect of different $\mathrm{pH}$ values on the percentage dissolution of copper and cobalt was studied on both $\mathrm{Cu}-\mathrm{Co}$ oxide ore (figure $5 \mathrm{~A}$ ) and sulphide (figure 5B). The leaching investigation took place at varying $\mathrm{pH}$ values of $0.5 ; 1$ and 1.5 in accordance with the thermodynamic prevision of the Eh-pH diagram. In the $\mathrm{pH}$ range of 0.5 to 1.5 there is a possibility of having $\mathrm{Cu}$ and $\mathrm{Co}$ in their ionic states of $\mathrm{Cu} 2+$ and $\mathrm{Co} 2+$ (as shown later on figure 8 ) these ions can easily form complex bonds with (SO4)2- according to the general equations:

$\mathrm{MO}+\mathrm{H} 2 \mathrm{SO} 4 \rightarrow \mathrm{MSO} 4+\mathrm{H} 2 \mathrm{O}$ for the oxide source and

$\mathrm{MS}+2 \mathrm{H} 2 \mathrm{SO} 4 \rightarrow \mathrm{MSO} 4+\mathrm{SO} 2+2 \mathrm{H} 2 \mathrm{O}$ for the sulphide source (where $\mathrm{M}$ is $\mathrm{Cu}$ or $\mathrm{Co}$ in the divalent state). 

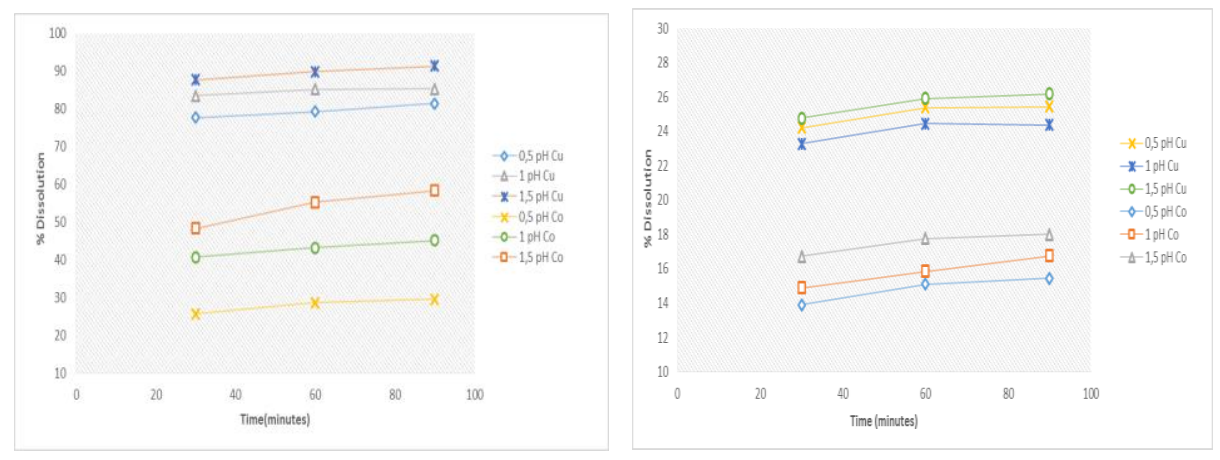

Figure 5. Effect of different $\mathrm{pH}$ values on the \%dissolution of copper and cobalt in oxide (A) and sulphide (B) ore.

According to the results illustrated in figure $5 \mathrm{~A}$ it is seen that after $90 \mathrm{~min}$ at $\mathrm{pH} 1.5,91.4 \%$ of $\mathrm{Cu}$ and 58.4 $\%$ of Co were recovered from the oxide ore while from the sulphide ore shown in figure 5B which was experimented in the same conditions only $26.2 \%$ of $\mathrm{Cu}$ and $18 \%$ of Co were recovered. The low dissolution of $\mathrm{Cu}$ and $\mathrm{Co}$ from sulphide may be justified by the fact that, beside the fact that elementary $\mathrm{S}$ make these ores refractory, the formation of polysulphides, metal-deficient sulphides, jarosite and jarositelike compounds during the leaching passivate $\mathrm{Cu}$ and $\mathrm{Co}$ and makes their dissolution to decrease rapidly.

In both cases, in the oxide and the sulphide ores it was noticed low dissolution of Co. Most of mineral occurring in the copper belt region contain cobalt in the form of heterogenite (shown in figure 1) where it is in $2+$ and $3+$ states. Because the above described situation only cobalt $2+$ will pass into the solution. This requires the use of a reducing agent in order to reduce the remaining $\mathrm{Co}^{3+}$ to $\mathrm{Co}^{2+}$.

At a higher $\mathrm{pH}(>1.5)$ the leaching would produce solid compound of copper $\left(\mathrm{CuFeO}_{2}\right)$ and cobalt $\left(\mathrm{CoO} . \mathrm{Fe}_{2} \mathrm{O}_{3}\right)$ as illustrated in the Eh-pH diagram in figure 9 a) and b).

\subsubsection{Effect of temperature}
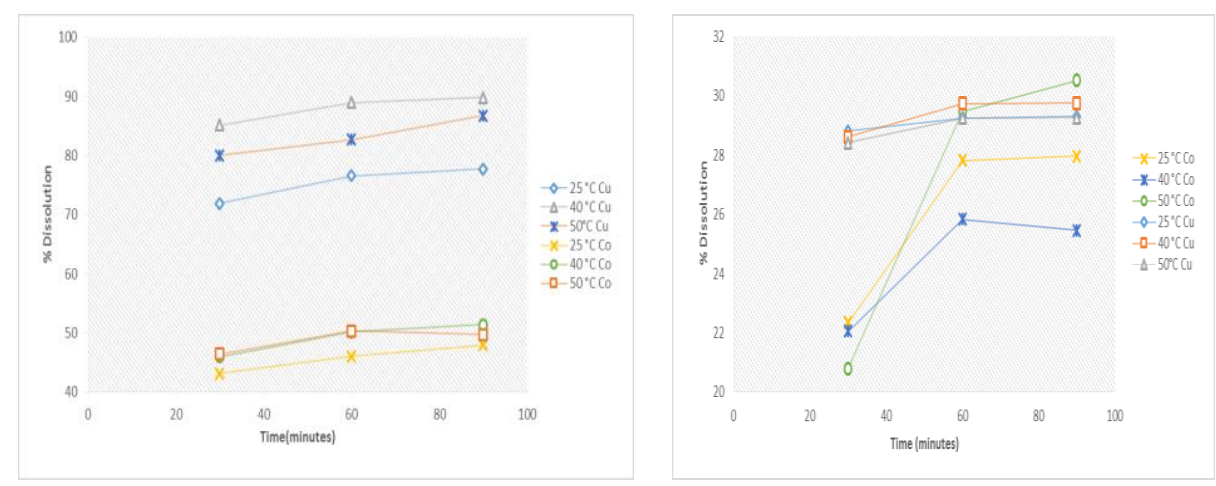

Figure 6: The effect of temperature on \%dissolution of copper and cobalt oxide (A) and sulphide (B) ore. 
The effect of temperature was also studied on the $\mathrm{Cu}$-Co oxide ore (figure $6 \mathrm{~A}$ ) and the sulphide ore (figure $6 \mathrm{~B})$. The experimental temperature values that were used in the present investigation were 25,40 and $50^{\circ} \mathrm{C}$. Results shown in figure 6 both $\mathrm{A}$ and $\mathrm{B}$ reveal that the dissolution of both copper and cobalt were affected by the increase in temperature since the rate of reaction is directly linked to the increase of temperature. It is noticed that the dissolution of $\mathrm{Cu}$ and $\mathrm{Co}$ increased with the increase in temperature from $25 \mathrm{OC}$ to $40 \mathrm{OC}$ then decreased at $50 \mathrm{OC}$. According to the results shown in figure $6 \mathrm{~A}$, after 90 minutes of leaching, it is noticed that $89.8 \%$ of $\mathrm{Cu}$ and $49.7 \%$ were recovered from the oxide ore on the other hand as shown on figure $3 \mathrm{~B}$ after 90 minutes of leaching only $29.8 \%$ and $25.5 \%$ of $\mathrm{Cu}$ and Co were respectively recovered from the sulphide ore. The low percentage dissolution of cobalt and copper from the sulphide ore can still be justified by the fact that it a refractory ore and it cannot be recovered by traditional (conventional) methods.

3.1 Leaching with sulphuric acid in conjunction with hydrogen peroxide of $\mathrm{Cu}$-Co sulphide ore (Part B).

Leaching of copper sulphide ore only with varying $\mathrm{H}_{2} \mathrm{O}_{2}$ volumes and $1 \mathrm{M} \mathrm{H}_{2} \mathrm{SO}_{4}$. Due to the fact that it was noticed there was low percentage dissolution of $\mathrm{Cu}$ and $\mathrm{Co}$ during the leaching of sulphide ores, the use of an oxidizing agent was compulsory to oxidise the sulphide ore making it easier to leach the targeted metal. Therefore, the effect of varying the concentration of hydrogen peroxide when leaching with sulphuric acid on $\mathrm{Cu}$-Co sulphide ore was studied as shown in figure 7 below, the volume of hydrogen peroxide was varied at 10, 20, 40 and $50 \mathrm{~mL}$.

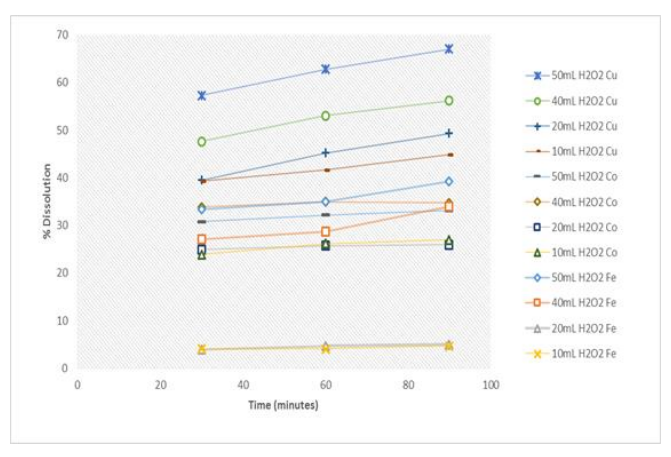

Figure 7. Effect of $\mathrm{H}_{2} \mathrm{O}_{2}$ on dissolution of copper, cobalt and iron at $\mathrm{pH} 1.5$

The experiment where $10 \mathrm{~mL}$ of hydrogen peroxide was added to the leaching system yielded $44.8 \% \mathrm{Cu}$ and $27.0 \%$ Co .Adding $10 \mathrm{~mL}$ dissolved the least copper and cobalt into solution, with cobalt increasing at a steady rate and copper increasing rapidly.

When $20 \mathrm{ml}$ of hydrogen peroxide was added the percentage dissolution of copper was $49.3 \%$ and cobalt $27.2 \%$. These results show that hydrogen peroxide have a significant impact on the recovery of copper and cobalt, as compared to adding $10 \mathrm{~mL}$ of hydrogen peroxide the recovery shows an increase.

The results of adding $40 \mathrm{~mL}$ of hydrogen peroxide yielded higher percentage dissolution as compared to adding 10 and $20 \mathrm{~mL}$ of hydrogen peroxide. The results show that $56.1 \%$ of $\mathrm{Cu}$ and $34.0 \%$ of $\mathrm{Co}$ was recovered.

The final experiment was conducted by adding $50 \mathrm{~mL}$ of hydrogen peroxide which yielded the highest copper and cobalt recovery at $67.0 \%$ and $34.2 \%$. These findings reveal that with increasing volume of hydrogen peroxide added to the leaching system the greater the percentage dissolution of both copper and cobalt within the 90 minutes of leaching. 
It is expected that when adding a significant amount of hydrogen peroxide the leaching potential should increase, this experiment proved this theory correct as the highest potential $(\mathrm{mV})$ was obtained with adding $50 \mathrm{~mL}$ of hydrogen peroxide, which increased from $-1.52 \mathrm{mV}$ to $960 \mathrm{mV}$, this is further explained in figure 9 (further below). This is because hydrogen peroxide is a strong oxidising agent thus promoting oxidation, in this case hydrogen peroxide oxidises the copper sulphide, therefore increasing the percentage dissolution of copper. As shown before, the percentage dissolution of both copper and cobalt in sulphide ore was lower when leaching without hydrogen peroxide but after the addition of hydrogen peroxide the percentage dissolution of copper and cobalt increased ,this is supported further graphically in figure 8 (further below).

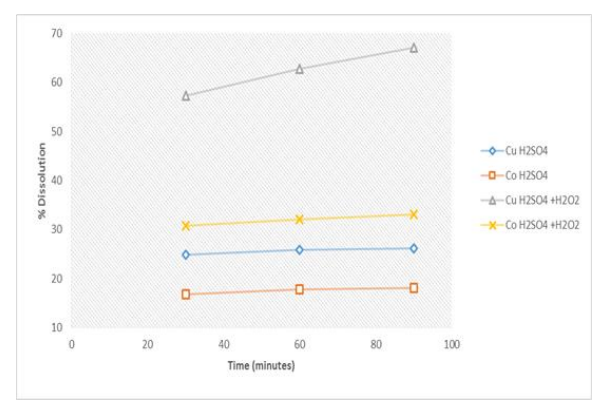

Figure 8.leaching with sulphuric acid (1M) only and leaching with sulphuric acid in conjunction with hydrogen peroxide $(50 \mathrm{~mL})$ of $\mathrm{Cu}-\mathrm{Co}$ sulphide ore at $1.5 \mathrm{pH}$

The results in figure 8 illustrate the comparison of leaching with sulphuric acid only and leaching with sulphuric acid mixed with hydrogen peroxide, these experiments are performed using $\mathrm{Cu}$-Co sulphide ore. The objective of this experiment is to justify the efficiency of hydrogen peroxide on the percentage dissolution of copper and cobalt which is evident looking at that copper increased from $26.2 \%$ without adding hydrogen peroxide to $67.1 \%$ when adding $(50 \mathrm{~mL})$ hydrogen peroxide. As for cobalt it was also seen to increase from $18 \%$ to $33.1 \%$ when leaching in conjunction with hydrogen peroxide.
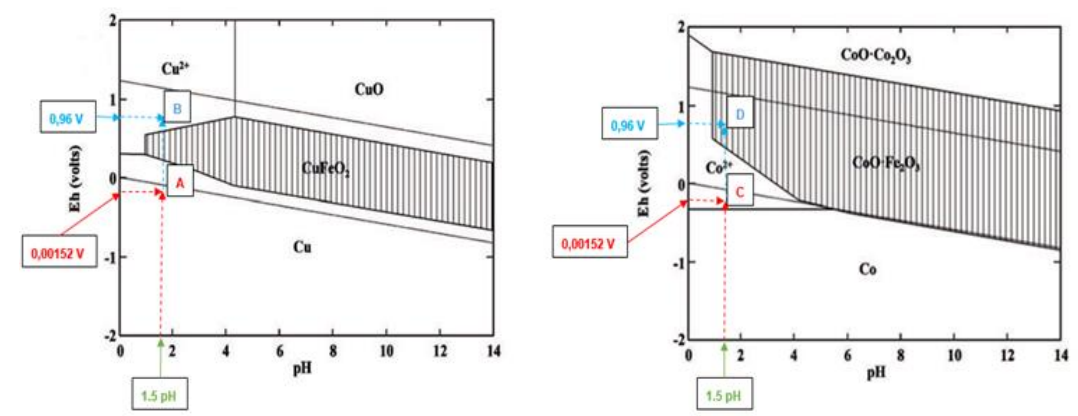

Figure 9. Eh-pH diagrams for $\mathrm{Cu}$ system (A) and Co system (B) showing the effect of adding hydrogen peroxide on the leaching potential 
Hydrogen peroxide plays an important role in this leaching experiment, the above figure is still based on the leaching with and without hydrogen peroxide experiment which shows the effect of hydrogen peroxide thermodynamically. Leaching of $\mathrm{Cu}-\mathrm{Co}$ sulphide ore with sulphuric acid only at $1.5 \mathrm{pH}$ measured a potential of $0.00152 \mathrm{~V}$ but when hydrogen peroxide was added the potential measured $0.96 \mathrm{~V}$ which causes a shift in the positioning of the aqueous electrochemical system, seeing figure $9 \mathrm{~A}$ for copper the aqueous system was repositioned to $\mathrm{Cu} 2+$ ionic boundary from a Cu stable state boundary. According to figure 9B the results show that for cobalt the aqueous system repositioned from stable Co to $\mathrm{CoO} . \mathrm{Fe} 2 \mathrm{O} 3$ ionic boundary after the addition of hydrogen peroxide. This experiment proves that the hydrogen peroxide (oxidizing agent) did increase the leaching potential (Eh) of the system thus increasing percentage dissolution for both copper and cobalt.

3.2 Leaching with sulphuric acid in conjunction with hydrogen peroxide of mixed $\mathrm{Cu}-\mathrm{Co}$ oxide and sulphide ore (Part C).

The effect of varying the ratios of oxide and sulphide copper ore while adding $10 \mathrm{~mL}$ of $\mathrm{H} 2 \mathrm{O} 2$ was studied, varying oxide: sulphide ore at 90:10, 80: 20 and 70:30. The results shown in figure 10 showed that when mixing oxide and sulphide ores at a ratio of 70:30; $62.0 \%$ of $\mathrm{Cu}$ and $26.0 \%$ of Co were recovered. This was the lowest percentage dissolution when compared to the other experiments that were conducted.

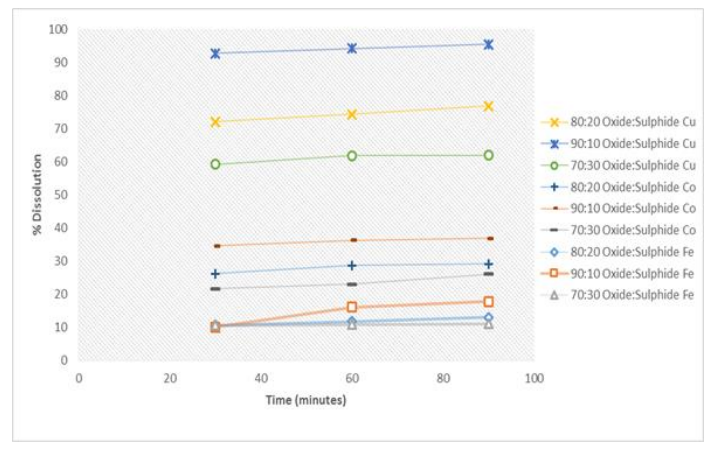

Figure 10. Effect of ratio of oxide and sulphide $\mathrm{Cu}-\mathrm{Co}$ ore on the \%dissolution of copper, cobalt and iron

The experiment where the ore ratio of 80:20 was used yielded a higher recovery than the 70:30 ore ratio in both metals. The percentage dissolution of the metals in this experiment was $76.8 \% \mathrm{Cu}$ and $29.1 \% \mathrm{Co}$.

The ratio of 90: 10 showed a high percentage dissolution of copper at 95.4\%. This finding is reasonable because most of the copper was in oxide form ("90") than in sulphide ("10") and it has been proven in experiments discussed earlier that $\mathrm{Cu}-\mathrm{Co}$ oxide ore respond to leaching very well with or without an oxidizing agent. Still referring to figure 10 the percentage dissolution of cobalt was also affected by the varying ratios of the oxide and sulphide ore. Amongst the ratios again 90:10 showed higher percentage dissolution of just $36.8 \%$, this finding was the same for the percentage dissolution of iron which was higher at a ratio of 90:10 at a recovery of $17.7 \%$.

\section{Conclusions}

The effects of leaching with sulphuric acid only and leaching with sulphuric acid in conjunction with hydrogen peroxide were investigated. The following was observed:

Part A: Leaching the oxide ore and sulphide ore separately with sulphuric acid only. 
The recovery of copper and cobalt increased by employing the most efficient conditions of the leaching parameters which are particle size, $\mathrm{pH}$ and temperature.

The particle sizes -75 and $+75 \mu \mathrm{m}$ were found to be more efficient yielding higher percentage dissolutions than other particle sizes $(+106 \mu \mathrm{m})$ used in the study. The results showed that the highest percentage dissolution was $96.2 \% \mathrm{Cu}$ and $43.9 \%$ Co when leaching oxide ore and for sulphide ore $28.5 \% \mathrm{Cu}$ and $17.7 \%$ Co was obtained. At at $1.5 \mathrm{pH}$ higher percentage dissolution of copper and cobalt were obtained than when leaching at 0.5 and $1 \mathrm{pH}$. The highest percentage dissolution was found to be $91.4 \% \mathrm{Cu}$ and $58.4 \% \mathrm{Co}$ in oxide ore and for sulphide ore it was found to be $26.2 \% \mathrm{Cu}$ and $18.0 \% \mathrm{Co}$.

The influence of the temperature showed that the percentage of copper and cobalt dissolved increased when the temperature increased. The highest percentage dissolution obtained was $89.8 \% \mathrm{Cu}$ and $51.4 \%$ Co in oxide ore and $29.3 \% \mathrm{Cu}$ and $30.4 \%$ Co for suplhide ores.

Part B: Leaching the sulphide ore with sulphuric acid in conjunction with hydrogen peroxide.

As observed earlier, leaching the sulphide ores with sulphuric acid only yielded very low copper and cobalt, which was not satisfactory thus a need for an oxidizing agent.

The effect of varying the concentration of hydrogen peroxide when leaching with sulphuric acid on sulphide ores showed that adding $50 \mathrm{~mL}$ of hydrogen peroxide was more efficient than 10,20 and $40 \mathrm{~mL}$. The results showed that copper increased from $26.2 \%$ to $67.1 \%$ when adding (50mL) hydrogen peroxide.

The cobalt increased from $18 \%$ to $33.1 \%$ when leaching in conjunction with hydrogen peroxide.

Part C: Leaching the mixed oxide and sulphide ore with sulphuric acid mixed with hydrogen peroxide.

Finally in this study the behavior of mixed ores was closely observed. Oxide and sulphide copper ore ratios were varied while adding $10 \mathrm{~mL}$ of hydrogen peroxide. From the results it was noticed that higher percentage of dissolution was obtained at a ratio of 90:10 with copper at $95.4 \%$ and cobalt at $36.8 \%$.

A final experiment was conducted using the optimum ore ratio of 90:10 (oxide: sulphide) and adding 50mL of hydrogen peroxide working at $\mathrm{pH} 1.5$ and 2.5. It was found that at $\mathrm{pH} 1.5$ higher percentage dissolution of copper, cobalt and iron was obtained. This finding was also supported thermodynamically that when leaching at $\mathrm{pH} 1.5$ it is more likely to position the $\mathrm{Co} / \mathrm{Cu} / \mathrm{Fe}$ aqueous system in an ionic boundary where copper, cobalt and iron are dissolving into solution. This study shows the significance of leaching at different $\mathrm{pH}$ values and how it affect the dissolution of copper and cobalt. The behavior of ferric iron should be well investigated to understand its influence on the leaching under this work conditions. 


\section{References}

[1] Rajko Ž. Vračara; Nataša Vučković and Željko Kamberovića:" Leaching of copper(I) sulphide by sulphuric acid solution with addition of sodium nitrate". Hydrometallurgy, Volume 70, Issues 1-3, July 2003, Pages 143-151

[2] E.M. Córdoba, J.A. Muñoz b, M.L. Blázquez b, F. González b and A. Ballester:“ Leaching of chalcopyrite with ferric ion. Part I: General aspects". Hydrometallurgy, Volume 93, Issues 3-4, August 2008, Pages 81-87

[3] E.M. Córdoba, J.A. Muñozb, M.L. Blázquezb, F. Gonzálezb and A. Ballester:“ Leaching of chalcopyrite with ferric ion. Part II: Effect of redox potential". Hydrometallurgy, Volume 93, Issues 3-4, August 2008, Pages 88-96

[4] E.M. Córdoba, J.A. Muñozb, M.L. Blázquezb, F. Gonzálezb and A. Ballester:“ Leaching of chalcopyrite with ferric ion. Part III: Effect of redox potential on the silver-catalyzed process". Hydrometallurgy, Volume 93, Issues 3-4, August 2008, Pages 97-105

[5] P. K. Abraitis; R. A. D. Patrick;; G. H. Kelsall and D. J. Vaughan:” Acid leaching and dissolution of major sulphide ore minerals: processes and galvanic effects in complex systems", Mineralogical Magazine, April 2004, Vol. 68(2), pp. 343-351.

[6] Klauber, C., 2008. A critical review of the surface chemistry of acidic ferric sulphate dissolution of chalcopyrite with regards to hindered dissolution. International Journal of Mineral Processing, 86(1-4): pp.1-17.

[7] Vaughan, D.J., 2006. Sulphide mineralogy and geochemistry: introduction and overview. In: D.J. Vaughan (Editor), Sulphide mineralogy and geochemistry. Reviews in mineralogy and geochemistry (Formerly: Reviews in mineralogy). Geochemical society mineralogical society of America, pp. 1-5.

[8] Keith, C.N. and Vaughan, D.J. (2000) Mechanisms and rates of sulphide oxidation in relation to the problems of acid rock (mine) drainage. Pp. 197_219 in: Environmental Mineralogy: Microbial Interactions, Anthropogenic influences. 